\title{
Dietary intake and barriers to dietary compliance in black type 2 diabetic patients attending primary health-care services
}

\author{
Gladys Nthangeni ${ }^{1}$, Nelia P Steyn ${ }^{2}, *$, Marianne Alberts ${ }^{3}$, Krisela Steyn ${ }^{2}$, Naomi S Levitt ${ }^{4}$, \\ Ria Laubscher ${ }^{5}$, Lesley Bourne ${ }^{6}$, Judy Dick ${ }^{7}$ and Norman Temple ${ }^{8}$ \\ ${ }^{1}$ Department of Human Nutrition, University of the North, Pietersburg, South Africa: ${ }^{2}$ Chronic Diseases of Lifestyle \\ (CDL) Unit, Medical Research Council, PO Box 19070, Tygerberg 7505, South Africa: ${ }^{3}$ Department of Medical \\ Sciences, University of the North, Pietersburg, South Africa: ${ }^{4}$ Department of Medicine, University of Cape Town, \\ South Africa: ${ }^{5}$ Centre for Epidemiological Research in Southern Africa, Medical Research Council, Cape Town, \\ South Africa: ${ }^{6}$ Health and Development Group, Medical Research Council, Cape Town, South Africa: ${ }^{7}$ Health \\ Systems Research Unit, Medical Research Council, Cape Town, South Africa: ${ }^{8}$ Centre for Science, Athabasca \\ University, Athabasca, Alberta, Canada
}

Submitted 9 May 2001: Accepted 15 August 2001

\begin{abstract}
Objective: To determine the dietary intake, practices, knowledge and barriers to dietary compliance of black South African type 2 diabetic patients attending primary health-care services in urban and rural areas.

Design: A cross-sectional survey. Dietary intake was assessed by three 24-hour recalls, and knowledge and practices by means of a structured questionnaire ( $n=133$ men, 155 women). In-depth interviews were then conducted with 25 of the patients to explore their underlying beliefs and feelings with respect to their disease. Trained interviewers measured weight, height and blood pressure. A fasting venous blood sample was collected from each participant in order to evaluate glycaemic control. Setting: An urban area (Sheshego) and rural areas near Pietersburg in the Northern Province of South Africa.

Subjects: The sample comprised 59 men and 75 women from urban areas and 74 men and 80 women from rural areas. All were over 40 years of age, diagnosed with type 2 diabetes for at least one year, and attended primary health-care services in the study area over a 3-month period in 1998.

Results: Reported dietary results indicate that mean energy intakes were low $(<70 \%$ of Recommended Dietary Allowance), 8086-8450 kJ day ${ }^{-1}$ and $6967-7382 \mathrm{~kJ} \mathrm{day}^{-1}$ in men and women, respectively. Urban subjects had higher $(P<0.05)$ intakes of animal protein and lower ratios of polyunsaturated fat to saturated fat than rural subjects. The energy distribution of macronutrients was in line with the recommendations for a prudent diet, with fat intake less than $30 \%$, saturated fat less than $10 \%$ and carbohydrate intake greater than $55 \%$ of total energy intake. In most respects, nutrient intakes resembled a traditional African diet, although fibre intake was low in terms of the recommended $3-6 \mathrm{~g} / 1000 \mathrm{~kJ}$. More than $90 \%$ of patients ate three meals a day, yet only $32-47 \%$ had a morning snack and $19-27 \%$ had a late evening snack. The majority of patients indicated that they followed a special diet, which had been given to them by a doctor or a nurse. Only 3.4-6.1\% were treated by diet alone. Poor glycaemic control was found in both urban and rural participants, with more than half of subjects having fasting plasma glucose above $8 \mathrm{mmoll}^{-1}$ and more than $35 \%$ having plasma glycosylated haemoglobin level above $8.6 \%$. High triglyceride levels were found in 24 to $25 \%$ of men and in 17 to $18 \%$ of women. Obesity (body mass index $\geq 30 \mathrm{~kg} \mathrm{~m}^{-2}$ ) was prevalent in 15 to $16 \%$ of men compared with 35 to $47 \%$ of women; elevated blood pressure $(\geq 160 / 95 \mathrm{mmHg})$ was least prevalent in rural women (25.9\%) and most prevalent in urban men (42.4\%).

Conclusions: The majority of black, type 2 diabetic patients studied showed poor glycaemic control. Additionally, many had dyslipidaemia, were obese and/or had an elevated blood pressure. Quantitative and qualitative findings indicated that these patients frequently received incorrect and inappropriate dietary advice from health educators.
\end{abstract}


Recent studies have indicated that the prevalence of type 2 diabetes mellitus is an increasing health concern in black South Africans. The age-adjusted prevalence of diabetes in urban settings was found to be $8 \%$ in Cape Town ${ }^{1}$ and $5.3 \%$ in Durban ${ }^{2}$. In peri-urban Xhosa speakers, the ageadjusted prevalence was found to be $4.5 \%{ }^{3}$ and in rural settings of Kwa-Zulu Natal, $4.2 \%{ }^{4}$. Numerous studies have demonstrated poor glycaemic control ${ }^{5}$, obesity ${ }^{6}$ and hypertension ${ }^{7}$ in the majority of black diabetic patients in South Africa.

The main goal of therapy for patients with type 2 diabetes is to optimise quality of life and to prevent acute metabolic and long-term complications with reduction of premature morbidity and mortality ${ }^{8}$. In managing the disease, dietary therapy should form an essential component of treatment. In this respect the Association for Dietetics in South Africa have published a position paper on the dietary management of type 2 diabetes? These recommendations focus on energy intake for optimal weight control, a high intake of dietary fibre (3$6 \mathrm{~g} / 1000 \mathrm{~kJ}$ ) and complex carbohydrates (50-65\% of total energy), a low fat intake $(<30 \%$ energy) and a low saturated fat intake $(<10 \%)$. Additionally regular meals and snacks are prescribed, with a limited alcohol intake and regular exercise as part of the lifestyle?

It is not known to what extent poor dietary compliance is a problem in black South African type 2 diabetic patients. One of the few studies that examined this question indicated that when dietary advice was the sole treatment, it appeared to have no effect on the metabolic control of the patients ${ }^{10}$. It has been suggested that nutrition therapy for black patients is unsuccessful when the diet prescription does not relate to the patient's cultural environment and economic situation, and is presented in ways that are difficult for low-literacy patients to understand and implement ${ }^{11}$.

To date there is a paucity of data on dietary intake and practices and dietary advice given to black type 2 diabetic patients who attend primary health-care services in South Africa. Due to the limited number of dietitians, particularly dietitians conversant in indigenous languages and culture, doctors and nurses currently give much of the dietary advice. The aim of this study was to evaluate the dietary intake and practices, the knowledge and barriers associated with dietary compliance, as well as metabolic control and associated disorders, in a group of urban and rural, black, type 2 diabetic patients. The results will assist in planning culturally appropriate dietary guidelines for black patients in a primary heath-care setting.

\section{Methods}

\section{Subjects and etbics}

The study was undertaken in the central region of the Northern Province of South Africa, in Sheshego, a suburb of the city of Pietersburg, and in surrounding rural areas
(40-100 km from Pietersburg). The Northern Province borders on Zimbabwe in the north and on Mozambique in the east. It is one of the most poverty-stricken provinces of the country due to its high unemployment rate ${ }^{12}$.

The sample comprised 59 men and 75 women from urban areas and 74 men and 80 women from rural areas, over 40 years of age, diagnosed with type 2 diabetes for at least one year and without renal failure. The participants were consecutive patients who attended primary healthcare services in the study area over a 3-month period in 1998. All patients visiting the clinics were willing to participate in the study.

Ethical approval for the study was obtained from the Ethics Committee of the University of the North. Informed consent was received from subjects prior to their inclusion in the study.

\section{Dietary intake}

The repeated 24-hour recall method was selected to assess the dietary intake of the participants as it is easy to administer, gives valid information on groups, and is practical to use with illiterate populations when the interviews are conducted by well-trained fieldworkers ${ }^{13}$. Participants were required to recall their entire previous day's food consumption. Interviews were conducted according to a training manual drawn up for the purpose of the survey. Interviews included two weekdays and a weekend recall for each participant. There was a period of at least 7 days between repetitions of the dietary questionnaire. The patients did not know in advance that their consumption on a specific day was to be studied. One interview was conducted at the home of each participant and the others at the clinics/hospital attended by the participant.

Four fieldworkers were trained by an experienced dietitian to conduct the dietary interviews. They were selected according to their practical experience in fieldwork as well as their ability to communicate in the local language (Pedi). Dietary aids (food models) were used by the fieldworkers to obtain detailed information on portion sizes consumed. The food models were selected based on average food portions and types of local foods commonly consumed in the northern areas of South Africa, as published in the literature ${ }^{14-17}$. Dietary data were analysed using SAS $^{18}$ and local food composition tables ${ }^{19}$. Mean nutrient intakes were compared with the Recommended Dietary Allowances (RDAs) ${ }^{20}$.

\section{Dietary practices, knowledge and treatment of the disease}

Questions on dietary practices and knowledge and treatment of the disease were incorporated into a general questionnaire developed for the purpose of the survey. The same fieldworkers who conducted the dietary interviews completed this questionnaire. Content validity ${ }^{21}$ 
was ensured by having the questionnaire evaluated by five experts in the field of type 2 diabetes and diet.

In order to explore the quantitative dietary data of these patients in more depth, in-depth interviews were conducted with 25 purposefully selected participants. The in-depth interview is regarded as one of the best qualitative research techniques to use in probing underlying meanings and values ${ }^{22}$. A Northern Sothospeaking woman, experienced in using qualitative methods, was further trained to do the in-depth interviews. Each interview was audio taped, then transcribed, translated into English and prepared for content analysis.

\section{Biochemical tests and antbropometry}

Fasting venous blood samples were collected from patients into tubes containing ethylenediaminetetraacetic acid (EDTA) for glycosylated haemoglobin (HbA1c) analysis, into tubes containing fluoride for glucose analysis and into plain tubes for lipid analyses. Blood samples were centrifuged within $6 \mathrm{~h}$ on a Beckman GF-15 centrifuge at $3000 \mathrm{rev} \mathrm{min}^{-1}$ for $15 \mathrm{~min}$, and supernatant stored at $-70^{\circ} \mathrm{C}$ until analysed. The analyses were done within 6 months from the day of collection. Glucose was measured with a Tecknicon RA-XT autoanalyser and a glucose oxidase kit. Glycosylated haemoglobin was measured using the IMX system, with a reference range of 4.3-6.6\%. Total cholesterol (TC), high-density lipoprotein cholesterol (HDL-C) and triglycerides (TG) were measured using a Dimension ES autoanalyser with kits supplied by Dade Behring. Low-density lipoprotein cholesterol (LDL-C) values were estimated using the Friedewald formula ${ }^{23}$ : LDL-C = TC-(HDL-C+TG/2.2). Reference values for glucose, HbA1c and lipids are shown in Table $6^{8,24-26}$.

Trained fieldworkers measured weight, height and blood pressure of each patient according to standard procedures $^{27}$. Weight was measured on a digital scale to the nearest $0.01 \mathrm{~kg}$; height on an anthropometer to the nearest $0.1 \mathrm{~cm}$; and body mass index (BMI) was calculated (weight/height squared). The blood pressure was measured with the person seated and rested for at least 5 minutes, using a mercury manometer (sphygmomanometer) that had been calibrated to the nearest $0.01 \mathrm{mmHg}^{28}$. Consecutive measurements were taken on the right arm. The mean of three readings was used for analysis.

\section{Pilot study}

A pilot study was undertaken on 20 diabetics (10 men and 10 women) at a clinic in the Northern Province that was not included in the sample area. The general questionnaire, as well as the 24-hour recall recording form, were tested and adapted accordingly.

\section{Statistical analyses}

To test for differences between urban and rural subjects, the Wilcoxon two-sample test was used for continuous variables and either the Chi-square test or Fisher's exact test was used for categorical variables. The 95\% confidence interval was used to test for significance.

\section{Results}

The mean age of the participants in the urban and rural areas was 62.2 (standard deviation (SD) 10.1) and 61.9 (9.8) years, respectively. The percentage of illiteracy was 18.6 and 22.7 for urban men and women and 29.7 and 24.4 for rural men and women, respectively. More than $70 \%$ of all the patients studied lived on a state pension (social security) or disability grant. Hypertension had been diagnosed in 53-63\% of men and in 55-61\% of women. The majority of men (66-68\%) and women (93-96\%) reported that they were taking oral hypoglycaemic agents, and $27 \%$ of men and $3-5 \%$ of women were using insulin.

\section{Dietary intake}

The reported energy and macronutrient intakes of the patients are presented in Table 1. Mean energy intakes of all groups were less than $70 \%$ of the RDA's minimum range (RDA for men, $9660 \mathrm{~kJ} \mathrm{day}^{-1}$; for women, $\left.7980 \mathrm{~kJ} \mathrm{day}^{-1}\right)^{20}$. Mean protein intakes were above the RDA for men and women (63 and $50 \mathrm{~g} \mathrm{day}^{-1}$, respectively). Total mean fibre intakes were low compared with the minimum recommended amounts of $29 \mathrm{~g}$ for men and $24 \mathrm{~g}$ for women, based on 3-6 g fibre per $1000 \mathrm{~kJ}$ per day? Mean fat and animal protein intakes were low and resulted in mean cholesterol intakes below the recommended maximum $\left(300 \mathrm{mgday}^{-1}\right)^{29}$. The main differences between mean intakes of urban versus rural subjects were found in animal protein, saturated fat (not significant) and in the polyunsaturated to saturated fat $(\mathrm{P} / \mathrm{S})$ ratio. Urban subjects had higher intakes of animal protein and saturated fat and lower $\mathrm{P} / \mathrm{S}$ ratios than their rural counterparts. Mean reported alcohol intakes were low $\left(<5 \mathrm{~g} \mathrm{day}^{-1}\right)$ in all groups.

Energy distribution of subjects in the present study complies well with the distribution of macronutrients recommended by the South African Dietetic Association? for the dietary management of type 2 diabetes (Table 1 ). Total mean fat intakes were far below the recommended maximum of 30\% and mean saturated fat intakes lay below $10 \%$ of energy intake. Carbohydrate intakes were far above the recommended minimum of $55 \%$ of energy intake. The high carbohydrate intake can be explained by the finding that the most commonly consumed foods were refined maize porridge, brown bread and/or sorghum, which were consumed in large quantities (Table 2). Chicken, beef and milk were the most frequently consumed sources of protein, and cabbage and spinach the most commonly consumed vegetables.

\section{Dietary practices and knowledge}

In both urban and rural areas, the majority of patients 
Table 1 Mean energy (SD) and macronutrient intakes in type 2 diabetic patients in the study

\begin{tabular}{|c|c|c|c|c|c|c|}
\hline Nutrients & $\begin{array}{l}\text { Urban men } \\
(n=59)\end{array}$ & $\begin{array}{l}\text { Rural men } \\
(n=74)\end{array}$ & $\begin{array}{c}\text { Urban/rural } \\
\text { Wilcoxon } \\
P \text {-value }\end{array}$ & $\begin{array}{l}\text { Urban women } \\
\quad(n=75)\end{array}$ & $\begin{array}{l}\text { Rural women } \\
\quad(n=82)\end{array}$ & $\begin{array}{c}\text { Urban/rural } \\
\text { Wilcoxon } \\
P \text {-value }\end{array}$ \\
\hline Energy (kJ) & 8449 (1881) & 8086 (1906) & 0.29 & 7381 (1894) & 6967 (1816) & 0.19 \\
\hline Protein (g) & 75 (18.1) & $70(21.6)$ & 0.07 & 65 (22.3) & $59(17.5)$ & 0.15 \\
\hline Plant protein (g) & 44 (12.6) & $43(11.2)$ & 0.80 & 39 (12.6) & 39 (12.4) & 0.85 \\
\hline Animal protein (g) & $31(14.0)$ & $26(18.4)$ & $0.018^{*}$ & $26(18.6)$ & $20(13.4)$ & 0.09 \\
\hline Total fibre $(\mathrm{g})$ & $21(6.3)$ & $21(6.8)$ & 0.47 & $21(8.6)$ & $19(6.7)$ & 0.50 \\
\hline Insoluble fibre (g) & $2.5(1.6)$ & $2.7(2.1)$ & 0.95 & $2.6(1.6)$ & $3.1(1.7)$ & 0.07 \\
\hline Soluble fibre $(\mathrm{g})$ & $2.0(1.3)$ & $2.3(2.5)$ & 0.54 & $2.2(1.6)$ & $2.3(1.7)$ & 0.54 \\
\hline Total carbohydrate (g) & $336(83.7)$ & $322(79.5)$ & 0.31 & $288(74.3)$ & $274(81.5)$ & 0.24 \\
\hline Total sugar (g) & $15(10.6)$ & $12(12.0)$ & 0.10 & $16(10.8)$ & $14(11.8)$ & 0.13 \\
\hline Added sugar (g) & $2.6(5.2)$ & $3.8(11.0)$ & 0.79 & $4.0(7.2)$ & $2.1(5.1)$ & 0.18 \\
\hline Cholesterol (mg) & 118 (77.9) & $114(102.5)$ & 0.27 & $126(118.7)$ & $105(92.6)$ & 0.38 \\
\hline Fat (g) & 30 (11.3) & 29 (12.9) & 0.33 & $28(12.8)$ & 27 (11.3) & 0.82 \\
\hline Saturated fat $(\mathrm{g})$ & $7.6(4.0)$ & $7.1(4.4)$ & 0.27 & $7.2(5.1)$ & $6.1(3.4)$ & 0.36 \\
\hline Monounsaturated fat (g) & $10.2(5.1)$ & $9.3(5.1)$ & 0.22 & $9.0(5.0)$ & $8.9(4.7)$ & 0.93 \\
\hline Polyunsaturated fat $(\mathrm{g})$ & $8.1(4.0)$ & $8.1(4.0)$ & 0.60 & $7.4(3.2)$ & $8.2(3.6)$ & 0.12 \\
\hline $\mathrm{P} / \mathrm{S}$ ratio† & $1.2(0.5)$ & $1.4(0.7)$ & 0.27 & $1.3(0.6)$ & $1.5(0.6)$ & $0.019^{*}$ \\
\hline Alcohol (g) & $1.9(9.0)$ & $0.4(2.3)$ & 0.45 & $0.9(4.4)$ & $0.9(4.5)$ & 0.76 \\
\hline Total protein as \% energy & $15.1(2.6)$ & $14.4(2.7)$ & 0.12 & $14.7(2.9)$ & $14.3(2.6)$ & 0.73 \\
\hline Plant protein as \% energy & $8.6(1.2)$ & $9.0(1.2)$ & 0.07 & $8.9(1.4)$ & $9.2(1.2)$ & $0.037^{\star}$ \\
\hline Animal protein as \% energy & $6.4(4.4)$ & $5.3(3.3)$ & $0.046^{*}$ & $5.8(3.7)$ & $4.9(3.1)$ & 0.29 \\
\hline Total fat as \% energy & $13.6(4.6)$ & $13.3(4.5)$ & 0.72 & $14.0(4.3)$ & $14.8(5.6)$ & 0.60 \\
\hline Saturated fat as \% energy & $3.4(1.8)$ & $3.3(1.7)$ & 0.46 & $3.6(2.1)$ & $3.4(1.8)$ & 0.57 \\
\hline Monounsaturated fat as \% energy & $4.7(2.3)$ & $4.3(1.8)$ & 0.57 & $4.5(1.8)$ & $4.9(2.4)$ & 0.43 \\
\hline Polyunsaturated fat as \% energy & $3.7(1.2)$ & $3.8(1.7)$ & 0.71 & $3.8(1.1)$ & $4.5(1.8)$ & $0.015^{\star}$ \\
\hline Carbohydrate as \% energy & $66.4(5.4)$ & $67.0(5.7)$ & 0.39 & $65.9(5.8)$ & $65.7(6.3)$ & 0.84 \\
\hline Added sugar as $\%$ energy & $3.1(2.4)$ & $2.6(2.7)$ & 0.08 & $3.8(2.9)$ & $3.5(3.3)$ & 0.37 \\
\hline Alcohol as \% energy & $1.1(5.0)$ & $0.3(1.9)$ & 0.45 & $0.8(5.7)$ & $0.8(4.1)$ & 0.77 \\
\hline
\end{tabular}

*, $P<0.05$.

$\dagger \mathrm{P} / \mathrm{S}$ : ratio of polyunsaturated fats to saturated fats. 
Table 2 Food items most commonly consumed by type 2 diabetics in the study, as derived from three 24-hour recalls

\begin{tabular}{|c|c|c|c|c|c|c|c|c|c|c|c|c|c|c|}
\hline \multirow[b]{2}{*}{ Food } & \multicolumn{3}{|c|}{$\begin{array}{l}\text { Urban men } \\
(n=59)\end{array}$} & \multicolumn{3}{|c|}{$\begin{array}{l}\text { Rural men } \\
(n=74)\end{array}$} & \multirow{2}{*}{$\begin{array}{c}\text { Chi-square } \\
P \text {-value }\end{array}$} & \multicolumn{3}{|c|}{$\begin{array}{l}\text { Urban women } \\
\quad(n=75)\end{array}$} & \multicolumn{3}{|c|}{$\begin{array}{l}\text { Rural women } \\
\quad(n=80)\end{array}$} & \multirow{2}{*}{$\begin{array}{c}\text { Chi-square } \\
P \text {-value }\end{array}$} \\
\hline & $\%$ & Mean $(\mathrm{g})$ & SD & $\%$ & Mean (g) & SD & & $\%$ & Mean $(\mathrm{g})$ & SD & $\%$ & Mean $(\mathrm{g})$ & SD & \\
\hline Brown bread & 92 & 145 & 66 & 86 & 152 & 56 & 0.507 & 93 & 128 & 58 & 90 & 135 & 56 & 0.317 \\
\hline Maize porridge & 75 & 721 & 138 & 82 & 723 & 218 & 0.782 & 87 & 597 & 174 & 76 & 584 & 195 & 0.811 \\
\hline Tea (Ceylon) & 66 & 303 & 136 & 81 & 278 & 87 & 0.914 & 59 & 284 & 81 & 75 & 337 & 167 & 0.390 \\
\hline Sorghum porridge & 66 & 671 & 159 & 76 & 616 & 184 & 0.097 & 69 & 560 & 203 & 79 & 596 & 146 & 0.143 \\
\hline Chicken & 76 & 94 & 31 & 76 & 99 & 33 & 0.784 & 72 & 96 & 38 & 69 & 100 & 45 & 0.783 \\
\hline Beef & 36 & 80 & 40 & 22 & 96 & 41 & 0.155 & 24 & 70 & 43 & 16 & 108 & 114 & 0.155 \\
\hline Milk & 28 & 165 & 100 & 30 & 99 & 23 & 0.174 & 25 & 171 & 139 & 23 & 133 & 105 & 0.180 \\
\hline Apple & 31 & 163 & 51 & 23 & 137 & 26 & 0.121 & 40 & 136 & 31 & 30 & 146 & 24 & 0.203 \\
\hline Cabbage & 25 & 109 & 52 & 50 & 114 & 79 & 0.815 & 27 & 86 & 32 & 38 & 101 & 61 & 0.598 \\
\hline Tea (herbal) & 22 & 281 & 93 & 18 & 242 & 35 & 0.332 & 47 & 314 & 103 & 30 & 310 & 107 & 0.883 \\
\hline Spinach & 20 & 208 & 77 & 39 & 116 & 48 & $0.000^{*}$ & 31 & 136 & 84 & 29 & 130 & 53 & 0.602 \\
\hline Oranges & 20 & 174 & 59 & 27 & 205 & 52 & 0.193 & 47 & 184 & 62 & 35 & 168 & 64 & 0.317 \\
\hline
\end{tabular}

${ }^{*}, P<0.05$.

Table 3 Practices related to dietary regimes of patients in the study

\begin{tabular}{|c|c|c|c|c|c|c|}
\hline Dietary advice given & $\begin{array}{l}\text { Urban men } \\
(n=59)(\%)\end{array}$ & $\begin{array}{l}\text { Rural men } \\
(n=74)(\%)\end{array}$ & $P$-value & $\begin{array}{l}\text { Urban women } \\
(n=75)(\%)\end{array}$ & $\begin{array}{l}\text { Rural women } \\
(n=80)(\%)\end{array}$ & $P$-value \\
\hline 1. Diet was explained by & 78 & 83.8 & 0.39 & 78.7 & 79.3 & 0.92 \\
\hline Doctor & 56.1 & 71.6 & 0.06 & 63.5 & 57 & 0.4 \\
\hline Dietitian & 15.8 & 8.1 & 0.17 & 4.1 & 14.3 & $0.03^{\star}$ \\
\hline Nurse & 22.8 & 12.2 & 0.11 & 18.9 & 27.3 & 0.22 \\
\hline Others & 3.5 & 1.4 & 0.58 & 1.4 & 3.9 & 0.62 \\
\hline 2. Diet explained to family & 0 & 0 & 0.71 & 0 & 1.2 & 0.69 \\
\hline \multicolumn{7}{|l|}{ 4. Years following the diet } \\
\hline$<1$ year & 8.7 & 16.2 & 0.34 & 18.7 & 13.4 & 0.83 \\
\hline $1-5$ years & 55.9 & 55.4 & & 56 & 59.8 & \\
\hline$\geq 5$ years & 35.6 & 28.4 & & 25.3 & 26.8 & \\
\hline \multicolumn{7}{|l|}{ 5. Comments on the diet } \\
\hline Expensive & 64.4 & 60.8 & 0.67 & 52 & 47.6 & 0.57 \\
\hline Unfamiliar foods & 8.5 & 2.7 & 0.13 & 14.7 & 11 & 0.48 \\
\hline Not tasty & 44.1 & 43.2 & 0.92 & 40 & 36.6 & 0.66 \\
\hline Not explained & 30.5 & 10.8 & $0.004^{*}$ & 24 & 20.8 & 0.62 \\
\hline Not traditional & 27.1 & 23 & 0.58 & 21.3 & 7.3 & $0.011^{*}$ \\
\hline Foods unavailable & 20.3 & 20.3 & 0.99 & 22.7 & 26.7 & 0.62 \\
\hline Other reasons & 5.1 & 4.1 & 0.77 & 6.7 & 2.4 & 0.21 \\
\hline \multicolumn{7}{|l|}{ Knowledge and practices } \\
\hline 1. What is diabetes? & & & 0.144 & & & 0.581 \\
\hline Correct & 27.1 & 39.2 & & 25.3 & 29.3 & \\
\hline Incorrect & 15.6 & 6.8 & & 14.7 & 11 & \\
\hline Unsure & 57.6 & 54.1 & & 58.7 & 59.8 & \\
\hline 2. What changes in blood? & & & $0.007^{*}$ & & & $0.007^{*}$ \\
\hline Correct & 6.9 & 24.3 & & 12 & 17.1 & \\
\hline Incorrect & 8.5 & 9.5 & & 9.3 & 18.3 & \\
\hline Unsure & 84.8 & 63.9 & & 77.3 & 64.6 & \\
\hline \multicolumn{7}{|c|}{ 3. Action taken when they believe they are hyperglycaemic? } \\
\hline Take medication & 59.3 & 63.5 & 0.62 & 56 & 56.1 & 0.99 \\
\hline Eat & 54.2 & 50 & 0.62 & 41.3 & 28.1 & 0.08 \\
\hline Sleep & 30.5 & 28.4 & 0.78 & 25.3 & 24.4 & 0.89 \\
\hline Visit clinic & 8.5 & 14.9 & 0.26 & 16 & 18.3 & 0.71 \\
\hline Nothing/other & 3.4 & 4.1 & 0.42 & 5.3 & 10.9 & 0.24 \\
\hline \multicolumn{7}{|c|}{ 4. Action taken when they believe they are hypoglycaemic? } \\
\hline Take medication & 56 & 54.1 & 0.829 & 52 & 31.7 & $0.010^{*}$ \\
\hline Eat & 54.2 & 46 & 0.342 & 48 & 22 & $0.001^{*}$ \\
\hline Sleep & 13.6 & 23 & 0.167 & 21.3 & 6.1 & $0.005^{*}$ \\
\hline Visit clinic & 3.4 & 5.4 & 0.578 & 9.3 & 9.8 & 0.92 \\
\hline Nothing/other & 3.4 & 0 & 0.697 & 5.3 & 6.1 & 0.55 \\
\hline
\end{tabular}

${ }^{*}, P<0.05$. 
(78-84\%) had had a 'diabetic' diet explained to them by either a doctor $(56-72 \%)$ or a nurse (12-27\%) (Table 3 ). Only $4-16 \%$ had been counselled by a dietitian. Most of the patients $(84-92 \%)$ stated that they followed the diet explained to them. However, less than $7 \%$ of men and women were using diet alone as a means of treatment for their diabetes. Apart from one rural woman, no diet had been explained to family members and less than half of the patients had received exchange lists, namely the recommended portion sizes within different food groups. Patients had many complaints about the dietary advice they had received: notably, that the diet was expensive, not tasty, not traditional and that foods were not available. Less than $40 \%$ of patients were able to give an explanation of their disease. Their practices also reflected poor knowledge, since more than 50\% of participants indicated that they take medication when hypoglycaemic and, conversely, eat when they are hyperglycaemic.

Table 4 presents a list of foods that patients had been counselled to eat, and those which were to be avoided. Generally, those foods recommended were healthy choices, being - with the exception of cheese - low in fat and in refined carbohydrates. Foods to be avoided included the main staple and traditional foods, namely maize porridge, tripe and intestines, and mageu, a fermented maize beverage. Also not recommended were red apples, sweet potatoes and mashed potatoes. Some food items fell into both categories, namely some educators told the patients to avoid them and some recommended their consumption. Bananas, oranges, green apples, whole milk, white rice and whiskey fell into this category.

More than $90 \%$ of patients ate breakfast, lunch and dinner (Table 5). Yet only $32-47 \%$ had a mid-morning snack, 44-65\% a mid-afternoon snack and only 19-27\% had a late-evening snack. It is also significant to note that although low alcohol consumption was reported in the 24-hour recalls, $16-25 \%$ of men indicated that they regularly consumed alcohol. Alcohol consumption was more common among men than women, and over weekends compared with weekdays.

\section{Qualitative data}

The in-depth interviews highlighted the confusion that patients experienced regarding the quantity and types of foods they were told to eat. Many patients had been told not to eat maize meal (a local staple food), white rice and white bread by health-care workers. In some cases they were told to avoid all starchy foods. Additional foods patients had been told to avoid which emerged from the in-depth interviews included: tripe and intestines, fullcream milk, fried eggs, red apples, oranges, bananas, grapes, mangoes, papaw (papaya), potatoes, sweet potatoes, salt, and all sweets and confectionery.

Participants were concerned and confused about the 
Table 5 Meal patterns and alcohol consumption of type 2 diabetic patients studied

\begin{tabular}{|c|c|c|c|c|c|c|}
\hline Meals & $\begin{array}{l}\text { Urban men } \\
(n=59)\end{array}$ & $\begin{array}{c}\text { Rural men } \\
(n=74)\end{array}$ & $\begin{array}{c}\text { Chi-square } \\
P \text {-value }\end{array}$ & $\begin{array}{l}\text { Urban women } \\
\qquad(n=75)\end{array}$ & $\begin{array}{l}\text { Rural women } \\
\quad(n=80)\end{array}$ & $\begin{array}{c}\text { Chi-square } \\
P \text {-value }\end{array}$ \\
\hline Breakfast, \% (number) & $100(59)$ & $97.3(72)$ & 0.50 & $100(75)$ & $98.8(79)$ & - \\
\hline Morning snack, \% (number) & $42.4(25)$ & $37.8(28)$ & 0.59 & 46.7 (35) & $32.1(26)$ & 0.07 \\
\hline Lunch, \% (number) & $100(59)$ & $93.2(69)$ & 0.06 & $100(75)$ & $92.6(75)$ & 0.06 \\
\hline Afternoon snack, $\%$ (number) & $55.9(33)$ & $48.6(36)$ & 0.40 & $65.3(49)$ & $44.4(36)$ & $0.01^{*}$ \\
\hline Dinner, \% (number) & $100(59)$ & $100(74)$ & - & $100(75)$ & $98.8(79)$ & - \\
\hline Evening snack, \% (number) & $27.1(16)$ & $21.6(16)$ & 0.46 & $24.0(18)$ & $18.5(15)$ & 0.42 \\
\hline Number of meals, mean (SD) & $4.3(1.0)$ & $4.0(1.1)$ & 0.16 & $4.4(1)$ & $3.9(0.9)$ & $0.001^{*}$ \\
\hline \multicolumn{7}{|l|}{ Number of foods per snack period } \\
\hline Morning snack, mean (SD) & $2.5(1.6)$ & $2.0(1.4)$ & 0.22 & $2.5(1.6)$ & $2.0(1.5)$ & 0.20 \\
\hline Afternoon snack, mean (SD) & $1.8(1.0)$ & $1.8(1.2)$ & 0.62 & $2.2(1.7)$ & $1.5(0.8)$ & $0.03^{*}$ \\
\hline Evening snack, mean (SD) & $0.6(1.9)$ & $1.4(0.7)$ & 0.73 & $1.2(0.5)$ & $1.9(1.9)$ & 0.21 \\
\hline \multicolumn{7}{|l|}{ Regular alcohol consumption } \\
\hline On weekdays, \% (number) & $17.0(10)$ & $16.2(12)$ & 0.91 & $1.3(1)$ & $4.9(4)$ & 0.36 \\
\hline On weekends, \% (number) & $25.4(15)$ & $17.6(13)$ & 0.26 & $4.0(3)$ & $6.1(5)$ & 0.72 \\
\hline
\end{tabular}

${ }^{*}, P<0.05$

amounts and portion sizes they were allowed to eat. This is illustrated by the following direct quotations:

'No, the doctor did not give me measurements, he just told me about the drink that we must drink'.

'Many doctors said you just eat porridge up to this limit' [showing the palm of the hand].

'I just eat like any other person'.

From the interviews it became apparent that these patients were receiving dietary advice from many sources. Apart from the health-care staff, the following were also consulted: relatives, other type 2 diabetic patients, traditional healers, Christian faith healers and herbalists.

Many of the participants indicated that they are 'forced' to eat certain foods they do not like. For example, 'We are forced to eat this dirty porridge' was said, referring to sorghum. Few of the patients knew or acknowledged that type 2 diabetes is a chronic condition that cannot be cured. Patients generally had a poor knowledge regarding their disease and treatment. This is illustrated by the following two statements:

'Sugar, they even surprised me because they said I must not eat sugar, but they say I must take a teaspoon of sugar when I feel dizzy'.

'Don't you understand me when I say that sometimes I just feel dizzy, I don't know what it is'.

The belief that their condition is curable has led many patients to try alternative treatments, including: raw chicken gallbladder, aloes (plant species), concoctions from the herbalist, nngu (indigenous vegetable), boiled litchi leaves, mopani worms (larvae of Imbrasia belina moth), salt water, prayer water and a dance by a traditional healer. Some also believe that the disease is the result of being bewitched, namely: 'Maybe it is not diabetes, maybe we are bewitched how will we know?' and 'Do you want to tell me that you don't know there are witches? If they hate you, they can hate you and do something, yes'.
Although some patients had been advised on what to eat, few had changed their eating habits. One reason given for this may be that the dietary advice was not culturally appropriate. This is illustrated by the following quotes:

'You know that in the Sotho, in our culture, I can't say I no longer eat it [maize meal], there are occasions where I am forced to be available, let me say funerals... when they put food on the corrugated iron, I also carry on eating. I just lie to myself and say after all it is one day it does not matter'.

'...It seems all doctors say the same thing that the beef tripe, goat, sheep and so on, don't eat, so I am used to them so much that I cannot stop eating them completely'.

'I don't like it when they say everything [all food] is not good for us'.

\section{Indicators of poor glycaemic control, dyslipidaemia, obesity and bypertension}

Poor glycaemic control was found in a large proportion of participants based on the South African guidelines for the management of type 2 diabetes at the primary care level ${ }^{8}$ (Table 6). This was the case for fasting serum glucose above $8 \mathrm{mmoll}^{-1}(59-67 \%)$ and for plasma HbA1c above 8.6\% (37-43\%).

Hypertriglyceridaemia, as defined in the South African guidelines, was found in $24-25 \%$ of males and in $17-18 \%$ of women. No subjects had abnormal HDL-C values according to the original South African guidelines. More recent and stricter criteria ${ }^{24}$ indicate that higher percentages had poor glycaemic control and dyslipidaemia, with 25 to $38 \%$ having low HDL-C values and more than $35 \%$ having abnormal LDL-C values. Obesity prevalence ranged from 15 to $16 \%$ in men and from 35 to $47 \%$ of women. A blood pressure $\geq 160 / 95 \mathrm{mmHg}$ was found in 33 to $42 \%$ of men and in 26 to $33 \%$ of women. Hypertension had been diagnosed in 53 to $63 \%$ of males 
Table 6 Percentage of type 2 diabetic patients with abnormal blood values, obesity and hypertension, and their medication usage

\begin{tabular}{|c|c|c|c|c|c|c|}
\hline Blood variable & $\begin{array}{l}\text { Urban men } \\
(n=57)\end{array}$ & $\begin{array}{l}\text { Rural men } \\
(n=73)\end{array}$ & $\begin{array}{c}\text { Chi-square } \\
P \text {-value }\end{array}$ & $\begin{array}{l}\text { Urban women } \\
\quad(n=74)\end{array}$ & $\begin{array}{l}\text { Rural women } \\
\qquad(n=80)\end{array}$ & $\begin{array}{c}\text { Chi-square } \\
P \text {-value }\end{array}$ \\
\hline \multicolumn{7}{|l|}{ Glucose } \\
\hline$>7 \mathrm{mmoll}^{-1 *}$ & 62.1 & 74.0 & 0.14 & 72.2 & 67.1 & 0.49 \\
\hline$>8 \mathrm{mmoll}^{-1} \dagger$ & 60.8 & 59.2 & 0.22 & 67.1 & 65.4 & 0.88 \\
\hline \multicolumn{7}{|l|}{$\mathrm{HbA} 1 \mathrm{c}$} \\
\hline$>7 \% *$ & 56.9 & 69.9 & 0.12 & 59.7 & 66.7 & 0.37 \\
\hline$>8.6 \% \dagger$ & 39.7 & 42.5 & 0.05 & 38.9 & 37.0 & 0.39 \\
\hline \multicolumn{7}{|l|}{ Triglycerides } \\
\hline$\geq 2 \mathrm{mmoll}^{-1 *}$ & 25.9 & 28.4 & 0.79 & 18.9 & 23.2 & 0.45 \\
\hline$\geq 2.2 \mathrm{mmoll}^{-1} \dagger$ & 24.1 & 24.7 & 0.95 & 17.5 & 17.0 & 0.94 \\
\hline \multicolumn{7}{|l|}{ Total cholesterol } \\
\hline$\geq 5 \mathrm{mmoll}^{-1 *}$ & 39.0 & 41.1 & 0.81 & 30.0 & 54.9 & 0.52 \\
\hline$\geq 6.5 \mathrm{mmoll}^{-1} \dagger$ & 5.2 & 11.0 & 0.49 & 14.9 & 9.8 & 0.25 \\
\hline \multicolumn{7}{|l|}{ HDL-C } \\
\hline$\leq 1.2 \mathrm{mmoll}^{-1 \star}$ & 35.6 & 30.1 & 0.51 & 37.8 & 25.0 & 0.09 \\
\hline$<0.9 \mathrm{mmoll}^{-1} \dagger$ & 0 & 0 & 0 & 0 & 0 & 0 \\
\hline \multicolumn{7}{|l|}{ LDL-C } \\
\hline$\geq 3 \mathrm{mmoll}^{-1}$ & 35.1 & 41.7 & 0.45 & 63.5 & 56.8 & 0.39 \\
\hline $\mathrm{BMI} \geq 30 \mathrm{~kg} \mathrm{~m}^{-2}$ & 15.3 & 16.2 & 0.85 & 46.7 & 35.4 & 0.15 \\
\hline \multicolumn{7}{|l|}{ Blood pressure } \\
\hline$\geq 140 / 90 \mathrm{mmHg}^{*}$ & 76.3 & 64.9 & 0.32 & 62.7 & 54.9 & 0.34 \\
\hline$\geq 160 / 95 \mathrm{mmHg} \dagger$ & 42.4 & 33.3 & 0.24 & 33.0 & 25.9 & 0.37 \\
\hline \multicolumn{7}{|l|}{ Medication } \\
\hline OHGA $\ddagger$ & 67.8 & 66.2 & 0.99 & 96.0 & 92.7 & 0.68 \\
\hline Insulin & 27.1 & 27.0 & & 2.7 & 4.9 & \\
\hline Other & 5.1 & 6.8 & & 6.7 & 2.4 & \\
\hline
\end{tabular}

Reference values: *, Working Group of the National Diabetes Advisory Board (SEMDSA) ${ }^{8}$; , Society for Endocrinal Metabolism and Diabetes of Southern Africa $^{24}$.

‡OHGA - oral hypoglycaemic agents.

and in 55 to $61 \%$ of females prior to the study. No significant differences were noted between urban and rural participants for biochemistry, blood pressure and anthropometry.

\section{Discussion}

This study has used a combination of quantitative and qualitative methods in order to gain a better understanding of the dietary intake, practices and beliefs of black type 2 diabetic patients in a particularly poor part of South Africa. When examining the diet from a nutritional point of view, it generally appears to follow the recommended guidelines ${ }^{9}$, even when taking the probability of dietary underreporting into consideration. The diet is high in carbohydrate (maize, sorghum and brown bread), and low in fat, particularly saturated fats. In this respect it reflects the traditional African diet. The low energy intake is very similar to that found in two recent studies in the Northern Province in black adults ${ }^{30,31}$, and possibly reflects some underreporting $^{32}$. This is probably due to the difficulty in establishing accurate portion sizes for maize porridge, which is eaten in large quantities by hand. A shortcoming of the nutritional intake of the patients is the finding that their fibre intake was below that recommended to bring about a reduction in LDL- $\mathrm{C}^{33}$, one of the benefits associated with a high dietary fibre intake.

The meal pattern described by patients did not conform to the recommendation of small frequent meals spaced throughout the day ${ }^{34,35}$. Major barriers to dietary compliance observed were related to foods allowed and to the patients' understanding of portion sizes. Patients were given conflicting advice with respect to the types of foods they were allowed to eat and they generally appeared to have little understanding of portion sizes, as illustrated by reports that they were not provided with exchange lists. A major concern is the finding that patients were told to avoid maize porridge and to eat sorghum instead. This does not make sense both culturally and scientifically, since maize is the traditional staple food of the region and additionally maize has been found to have a lower glycaemic index than sorghum, especially when eaten $\operatorname{cold}^{36}$. The finding that patients had a high intake of maize indicates that they were disregarding this recommendation in any event. Some fruits had also been contraindicated (e.g. red apples) without sound nutritional reason. At most health-care centres attended by black patients in South Africa, doctors and nurses counsel with respect to dietary treatment. Unfortunately, they have little training in nutrition and, additionally, may have poor knowledge with respect to foods that are traditionally eaten. Consequently, the dietary advice given is frequently inconsistent, sometimes incorrect and often confusing to patients $^{37}$.

The finding that a large proportion of these patients had poor glycaemic control, were hypertensive and overweight comes as no surprise, and echoes that of similar studies in black diabetic patients where it has been found 
that $76 \%$ of women were hypertensive and 54\% were obese $^{7}$.

The finding that patients in the present study were poorly controlled and overweight cannot be ascribed to their diet alone, since type 2 diabetes is known to be associated with several adverse cardiovascular risk factors, namely hypertension, increased serum triglycerides and decreased HDL-C ${ }^{38,39}$. Lifestyle factors such as lack of exercise, alcohol consumption and cigarette smoking could also have contributed to the poor glycaemic control and dyslipidaemia found in these patients, as well as poor compliance with medication.

\section{Conclusions}

The majority of black, type 2 diabetic patients studied showed poor glycaemic control. Additionally, many had dyslipidaemia, were obese and/or had an elevated blood pressure. Although it is difficult to determine the extent to which dietary compliance contributed to this, the following factors were identified as contributors: lack of knowledge regarding the disease; inadequate and inaccurate dietary counselling; and poor compliance with dietary advice given.

\section{Recommendations}

It is recommended that a culturally appropriate dietary intervention programme be developed for black type 2 diabetic patients. This should include a diet plan that is based on the traditional staple foods - maize and/or sorghum, and be spaced throughout the day in wellbalanced portion sizes. Patients should be encouraged to increase their fibre intake, e.g. by including legumes, which are culturally acceptable and have a low glycaemic index ${ }^{40}$. Additionally, patients need to be given accurate dietary and lifestyle information on their disease from doctors and nurses since they are the main nutrition educators. This may require that health professionals be retrained in the concepts of an optimal diabetic diet which is culturally and economically acceptable to black patients.

\section{Acknowledgements}

We thank the following organisations who contributed financially to this study: Medical Research Council, South African Sugar Association, Novo Nordisk, and the Norwegian Universities Committee for Development Research and Education (NUFU).

\section{References}

1 Levitt NS, Katzenellenbogen JM, Bradshaw D, Hoffman MN, Bonnici $F$. The prevalence and identification of risk factors for NIDDM in urban Africans in Cape Town, South Africa. Diabetes Care 1993; 16: 601-7.

2 Omar MAK, Seedat MA, Motala AA, Dyer RB, Becker P. The prevalence of diabetes mellitus and impaired glucose tolerance in a group of urban South African blacks. S. Afr. Med.J. 1993; 83: 641-3.

3 Erasmus RT, Blanco E, Okesina AB, Matsha T, Gqweta Z, Mes JA. Prevalence of diabetes mellitus and impaired glucose tolerance in factory workers from Transkei, South Africa. S. Afr. Med.J. 2001; 91: 157-90.

4 Motala AA, Pirie FJ, Gouws E, Omar MAK, Gray IP. The prevalence of diabetes mellitus and associated risk factors in a rural South African community of Zulu descent. $J$. Endocrinol. Metal. Diabetes S. Afr. 2001; 6: 39.

5 Levitt NS, Bradshaw D, Zwarenstein MF, Bawa AA, Maphumolo S. Audit of public sector primary diabetes care in Cape Town South Africa; high prevalence of complications, uncontrolled hyperglycaemia, and hypertension. Diabetes Med. 1997; 14: 1073-7.

6 Van Rooijen AJ, Rheeder P, Eales CJ. Urban black female patients' perception and knowledge of non-insulin dependent diabetes mellitus (NIDDM): a pilot study. J. Endocrinol. Metal. Diabetes S. Afr. 2001; 6: 38.

7 Mohamed E. The implementation of the national diabetes type 2 guidelines at primary level. J. Endocrinol. Metal. Diabetes S. Afr. 2001; 6: 38.

8 Working Group of the National Diabetes Advisory Board (SEMDSA). Guidelines for the management of type II (noninsulin-dependent) diabetes mellitus at primary health care level in South Africa. S. Afr. Med. J. 1997; 87: 497-512.

9 Association for Dietetics in Southern Africa. Dietary management of people with diabetes mellitus. Position Statement. $S$. Afr. J. Clin. Nutr. 1997; 9: 1233-4.

10 Erasmus RT, Blanco EB, Okesina AB, Gqweta Z, Matsha T. Assessment of glycaemic control in stable type 2 black South African diabetics attending a peri-urban clinic. Postgrad. Med.J. 1999; 75: 603-6.

11 Gohdes D. Diet therapy for minority patients with diabetes. Diabetes Care 1988; 11: 189-91.

12 Alberts M. The Dikgale Health and Demographic Study. Sovenga: University of the North, 1995.

13 Nelson M, Bingham SA. Assessment of food consumption and nutrient intake. In: Margetts BM, Nelson M, eds. Design Concepts in Nutritional Epidemiology, 2nd ed. Oxford: Oxford University Press, 1997.

14 Bourne LT, Langenhoven ML, Steyn K, Jooste PL, Laubscher R, Van der Vyfer E. Nutrient intake in the urban African population of the Cape peninsula South Africa. The Brisk Study. Central Afr. J. Med. 1993; 39: 238-48.

15 Ladzani R, Steyn NP, Nel JH. A socio-economic profile of households in semi-rural areas of Lebowa with specific reference to dietary habits. S. Afr. J. Food Sci. Nutr. 1992; 4: 60-3.

16 Gresse A, Voster HH. The glycaemic index and second meal effect of the typical African meal in black non-insulin dependent diabetic subjects. S. Afr. J. Food Sci. Nutr. 1992; 4: 64-9.

17 Gresse A, Voster HH. Eating habits and nutrient intakes of black patients with diabetes mellitus. S. Afr. J. Food Sci. Nutr. 1992; 4: 76.

18 SAS Institute, Inc. SAS User's Guide: Statistics, 5th ed. Cary, NC: SAS Institute, Inc., 1985.

19 National Research Programme for Nutritional Intervention. Food Composition Tables. Tygerberg: South African Medical Research Council, 1999.

20 Food and Nutrition Board, National Research Council Recommended Dietary Allowances, 10th ed. Washington, DC: National Academy Press, 1989.

21 Polit DF, Hungler BP. Nursing Research, Principle and Methods, 5th ed. Philadelphia, PA: Lippicot Company, 1995.

22 Ely M, Anzul M, Friedman T, Garner D, Steinmetz AM. Doing Qualitative Research: Circles within Circles. London: The Falmer Press, 1998. 
23 Friedewald WT, Levy RJ, Frederickson DS. Estimation of the concentration of low-density lipoprotein cholesterol in plasma without use of the preparative ultracentrifuge. Clin. Chem. 1972; 18: 499-502.

24 Society for Endocrinal Metabolism and Diabetes of Southern Africa. Guidelines for Type 2 Diabetes at Primary Care Level. Johannesburg: Servier, 1999.

25 Lipid and Atherosclerosis Society of Southern Africa Working Group. Diagnosis, management and prevention of the common dyslipidaemias in South Africa - clinical guidelines, 2000. S. Afr. Med.J. 2000; 90: 164-77.

26 Raubenheimer PJ, Levitt NS. What is good control in diabetes mellitus? Cont. Med. Educ. 2000; 18: 915-8.

27 Mahan LK, Escott-Stump S. Krause's Food, Nutrition, and Diet Therapy, 10th ed. Philadelphia, PA: WB Saunders Company, 2000.

28 World Health Organization (WHO). Arterial Hypertension. Report of a WHO expert committee. WHO Technical Reports Series No. 628. Geneva: WHO, 1978.

29 American Heart Association (AHA). Dietary guidelines for healthy American adults. Position statement. Circulation 1988; 77: 721A-4A.

30 Steyn NP, Burger S, Monyeki KD, Alberts M, Nthangeni G. Seasonal Variation in Dietary Intake of the Adult Population of Dikgale. Sovenga: University of the North, 1999.

31 Steyn NP, Senekal M, Brits S, Nel JH. Urban and rural differences in dietary intake, weight status and nutrition knowledge of black female students. Asia Pacific J. Clin. Nutr. 2000; 9: 53-8.

32 Steyn NP, MacIntyre UE, Olwagon R, Albert M. Validation of multiple 24-hour recalls in a rural adult population using energy intake and estimated basal metabolic ratios. Epidemiol Infec. 2001; 16(1): 23-6.

33 Nuttall FQ. Dietary fiber in the management of diabetes. Diabetes 1993; 42: 503-6.

34 Bertelsen JC, Christiansen C, Thomsen C, Poulsen PL, Vestergaard S, Steinov A, Rasmussen LH, Rasmussen O, Hermansen K. Effect of meal frequency on blood glucose, insulin, and free fatty acids. Diabetes Care 1993; 16: 4-7.

35 Jenkins DJ, Ocana A, Jenkins AL, Wolever TM, Vuksan V, Katzman HM, Greenberg G, Patten R. Metabolic advantages of spreading nutrient load: effects of increased meal frequency in non-insulin dependent diabetes. Am. J. Clin. Nutr. 1992; 55: 461-7.

36 Venter CS, Voster HH, Van Rooyen A, Kruger-Locke MM, Silvis N. Comparison of the effects of maize porridge consumed at different temperatures on blood glucose and acetate levels in healthy volunteers. S. Afr. J. Food Sci. Nutr. 1990; 2: 2-5.

37 Silvis N. Nutritional recommendations for individuals with diabetes mellitus. S. Afr. J. Food Sci. Nutr. 1992; 81: 162-6.

38 Turner RC, Millns H, Neil HAW, Stratton IM, Manley SE, Matthews DR, Holman RR. Risk factors for coronary artery disease in non-insulin dependent diabetes mellitus: United Kingdom prospective diabetes study (UKPDS: 23). BMJ 1998; 316: 823-8.

39 Grundy SM. Hypertriglyceridemia, atherogenic dyslipidemia, and the metabolic syndrome. Am. J. Cardiol. 1998; 81(4A): 18B-25B.

40 Mbenyane XG. The glycemic index of indigenous South African foods. PhD thesis, Potchefstroom Universiteit vir Christelike Hoer Onderwys, Potchefstroom, 1997. 